OPEN ACCESS

Edited by:

Nnaemeka Vincent Emodi, University of Queensland Business

School, Australia

Reviewed by:

Qinghua Huang,

Southwest University, China

Luigi Aldieri,

University of Salerno, Italy

Ehsan Elahi,

Shandong University of Technology,

China

Sevda Kușkaya,

Erciyes University, Turkey

*Correspondence:

Xing Niu

niuxing@ecust.edu.cn

Specialty section:

This article was submitted to

Environmental Economics and

Management

a section of the journal

Frontiers in Environmental Science

Received: 22 October 2021

Accepted: 20 December 2021

Published: 12 January 2022

Citation:

Wu G, Xu Q, Niu X and Tao L (2022) How Does Government Policy Improve

Green Technology Innovation: An

Empirical Study in China.

Front. Environ. Sci. 9:799794.

doi: 10.3389/fenvs.2021.799794

\section{How Does Government Policy Improve Green Technology Innovation: An Empirical Study in China}

\author{
Guancen $W u^{1}$, Qian $X u^{1}$, Xing $\mathrm{Niu}^{2 *}$ and $L i T a o^{1}$ \\ ${ }^{1}$ School of Management, Shanghai University, Shanghai, China, ${ }^{2}$ School of Social and Public Administration, East China \\ University of Science and Technology, Shanghai, China
}

This paper divides government policy according to policy quantity, policy effectiveness and policy executive force so that the government policy can be quantified in more detail. Green patent data is used to represent green technological innovation, and the fixed effect model and panel data analysis from 2010 to 2019 are employed. The empirical results show that government policy has a significant direct promoting effect on green technology innovation. And the positive impact of policy quantity and policy effectiveness on green technology innovation is greater than that of policy executive force. In addition, the government policy will weaken the positive effect of enterprise innovation vitality on green technology innovation. Research conclusions also show that the direct and indirect effects of government policies on green technology innovation are heterogeneous. The government still needs appropriately policies adapted to the local situation, coordinated in policy quantity, policy effectiveness, and executive force, and accelerate the establishment of market-oriented green technology innovation environment. Different regions also should find the right green technology innovation policy scheme for their own regions.

Keywords: green technology innovation, green patent, government policy, fixed effect model, enterprise

\section{INTRODUCTION}

Since the 21st century, green technology innovation has been an important emerging area of the global industrial revolution and technological competition. Green technology innovation was first proposed by Rhodes and Wield (1994) and described as "the research, development, and application of green technology, products, and processes, including the whole process of green technology from the source of research and development to the achievements transformation and the final marketization.” The United States, the United Kingdom, Germany, Japan and South Korea have developed their own green technology innovation regulations to promote the effectiveness of green technology innovation (Yang, 2016). The COVID-19 outbreak accelerated the pace of innovation in green technologies, and countries around the world have continued to adopt targeted green technology innovation policies. The Global Innovation Index (GII) annual report (2021) highlighted that improving the level of innovation in developing countries depends mainly on sustained policy support. As the only middle-income economy in the top 30 of the Global Innovation Index (GII) list, China is one of the countries with the highest number of patent applications. Over the past few years, China has increasingly emphasized the role of green technology innovation in sustainability and developed a series of institutional policies for improving levels of green technology innovation. Various provinces have also increased the policy support for green technology 
innovation. However, different policy quantities, effectiveness, executive force, will have different impacts on improving green technology innovation. Green technology innovation in various provinces has shown different development trends. Though the role of innovation policies has been highlighted and some qualitative descriptions of the relationships between policies and innovation are often presented, empirical research about the influence of green technology policies on green technology innovation is still lacking due to the complexity, time lag, and cumulative nature of policies (Lin et al., 2017; Diercks et al., 2019).

Patent data is often used to measure technological innovation, so green patents also can be used as the proxy variable of green technology innovation. Wang et al. (2019) analyzed the development of green technology innovation in China by using the environmental-related technology patent data from 1990 to 2015. Wang and Zhao (2019) analyzed the changing trend and spatiotemporal distribution of green technology innovation in China by using International Patent Classification (IPC) Green Inventory, which was developed in 2010 by the World Intellectual Property Group (WIPO), they found that provinces with higher levels of green technology innovation were mainly in the eastern and middle regions. Xia et al. (2021) also used green patent data to analyze the regional heterogeneity of China's green technology innovation, the research found that the eastern region was always in the dominant position, green technology innovation in China has a spatial difference that cannot be ignored.

Government policy can promote innovation activities both directly and indirectly. It originated from Keynesianism in the 1930s (Guo, 2018). Although enterprise capabilities have long been regarded as the main driving force of green technology innovation, special externalities of green technology innovation, such as technology spillover and high risk, make it easy for enterprises to lack the incentive to innovate, which is commonly known as market failure (Li et al., 2018; Zeng et al., 2020). In most cases, government-supporting policies can compensate for such market failures and limit the negative externalities of green technology innovation. For example, subsidy policy can stimulate the research and development of green technology innovation, financial support can cultivate and expanse the enterprise growth, patents policies can protect intellectual property, as well as sending policy signals, etc., (Wang and Zhao, 2019; Yan and Wu, 2020). The measurement of policy used in previous research mainly focuses on financial investment and tax incentives (He, 2014; Zeng et al., 2020). Some scholars have found that environmental regulation policies will increase costs and weaken the motivation of green technology innovation, thereby inhibiting innovation (Sinn, 2008; Pei et al., 2019). However, this inhibiting effect only exists at a certain stage. After passing a certain "inflection point," environmental regulation 81 policies can instead promote green technology innovation (Guo et al., 2018; Chen et al., 2019; Zhang et al., 2019). This type of research mainly uses pollution control indicators to measure environmental regulation policy. From the different results of policy on green technology innovation in previous research, we can see that the choice of policy proxy variables has a significant impact on research results, and different policy measurement methods lead to different results on the same issue.

In order to enable scholars to better classify and research policy instruments and their role, the Organization for Economic Cooperation and Development (OECD) has divided environmental policy into three categories: command control policy, market incentive policy, and social will policy (OECD, 1996). Based on this classification, some scholars used indicators such as environmental pollution control amount, sewage discharge fee, or government subsidy to represent policy variables and analyze the impact of different types of policy tools on green technology innovation (Yi et al., 2019; Shen et al., 2020). However, these measurements of policy are not direct enough and only focus on a single aspect. Content of innovation policy is complex and comprehensive, and always covers multiple aspects, sometimes policy mix may have the complementarity effect. Researchers try to measure the impact of comprehensive policy. Wang et al. (2018) analyzed the promotion effect of China's sustainable public procurement policy on science and technology innovation from the perspective of policymaking frequency and policymaking institutions, they pointed out that policymaking requires the participation of multiple institutions so that can form policy combinations, otherwise, the effectiveness of policy cannot be fully exploited. Zhao et al. (2021) noted that the role of government subsidy mechanism on green technology innovation differs among enterprises of different types. In addition, studies have shown that policy combination plays a significant role in guiding and accelerating the innovation of lowcarbon solutions (Rogge and Schleich, 2018; Rafael et al., 2019). Therefore, to more quantitatively reflect the effect of comprehensive policy based on the policy itself, Peng et al. (2008) quantified innovation policy from three dimensions of policy effectiveness, policy objectives, and policy measures, and formulated a quantitative policy manual. Some scholars adopted this quantitative method in their research related to the impact of policy (Zhang et al., 2016; Wang et al., 2018; Weng et al., 2018; Zhang et al., 2021).

There are regional differences in the impact of policy. Li et al. (2019) found that the effect of innovation policies is related to the level of local economic development, China's innovation policy is beneficial to more developed regions, which exacerbates the digital divide and spatial polarization. Li et al. (2020) found that the impact of funding on green technology progress began to vary across regions with the increase in environmental regulation in China. Some studies not only emphasized on the direct role of government policy on green technology innovation, but also focus on the indirect role and moderating effect of policy. Feng and Chen (2018) argues that environmental regulation policy has a positive direct impact on green innovation, but also positively regulates the impact of foreign direct investment on green innovation. Guo et al. (2018) found the interaction between environmental regulation and government R\&D will promote green product innovation and inhibit green process innovation from China Provincial Data. 
Other studies have analyzed the impact of energy policies, green finance policies, green investment, fiscal decentralization, credit ratings policies on the reduction of $\mathrm{CO}_{2}$ emissions in China, in emerging markets or in developed countries respectively (Bilgili et al., 2019; Kuşkaya and Bilgili, 2019; Ji et al., 2021a; Bilgili et al., 2021; Ji et al., 2021b; Hao et al., 2021; Li et al., 2021; Shen et al., 2021; Umar et al., 2021; Yu et al., 2022). Elahi and other researchers (Elahi et al., 2018; Elahi et al., 2019; Elahi et al., 2021a; Elahi et al., 2021b) focused on climatic factors, socio-psychological behavior and institutional and public policies regarding the use of farmland. Hong et al. (2019) investigated the moderating role of government incentive measures on the energy-saving behavior of residents.

China's Development Guidelines during the 14th period of the Five-Year Plan established the specific task of "strengthening legal and policy guarantees for green development." The National Development and Reform Commission (NDRC) and the Ministry for Science and Technology (MOST) have enacted the "Guidance on Building a Market-Oriented Green Technology Innovation System" in 2020. The strategic goals of reaching peak carbon dioxide emissions by 2030 and achieving carbon neutrality by 2060 were proposed at the 75 th session of the UN General Assembly in 2021, green technology innovation is an important engine and a key guarantee to achieve carbon neutrality. But in China, green technology innovation policy is generally implemented at the regional level, such as at the provincial level. Each province has independent development strategies of green technology innovation due to significant regional characteristics. Various local governments have enacted different local laws, regulations, normative documents and working papers. Linked to green technology innovation covers a broad range of areas, so related policies are scattered across multiple sectors and institutions. This has had an impact on the effectiveness of green technology innovation policies in the different provinces. Existing studies have not analyzed the effects of green technology innovation policy thoroughly, nor have they considered the effects of policy during their lifetime and on the current issued time. There the purpose of this paper is to discuss the following issues: What is the current situation of green technology innovation policy in different provinces of China? How does the policy quantity, policy effectiveness, and policy executive force affect green technology innovation? What is the mutual impact of government policy and enterprise innovation vitality on green technology innovation? Government policy mentioned in this paper refers to the green technology innovation policy, it is the sum of all government policies aiming at improving the green technology innovation, involving environmental protection, technology, talent, trade, finance, and other policy categories, among which green technology innovation policy is the core. This study will help to explore a feasible and effective path towards sustainable development for China and other countries around the world.

The main contribution of this study lies to collect data on policies quantity related to green technology innovation and to use them as policy variables instead of indirect indicators. This is a method for measuring mixing policy and more in line with the aim of this study. The presentation of two new indicators, policy effectiveness and policy executive force, deepens the scope of the study. The level of green technology innovation is measured more precisely by the IPC Green Inventory patent classification method than other proxy variables. Furthermore, the results obtained from the cross-analysis of policy variables with enterprise innovation vitality are also very significant. All findings will serve as a benchmark for the formulation of local green technology innovation policy in the future.

\section{RESEARCH HYPOTHESIS}

Innovation can help enterprises apply the right process technology to develop new products, meet market demand and eliminate competitive threats (Adler and Shenhar, 1990). Enterprises accumulate a large amount of capital, innovative human capital and other resources of green technology from research and development to production. Industrial organization theory believes the innovation vitality will also determine enterprise performance and the level of regional green technology innovation (Hou and Chen, 2018). Innovative vitality may include the ability to develop and adopt new products and process technologies to meet future needs as well as responsiveness.

Although the key driver of green technology innovation is enterprise, it also requires an appropriate environment to enable the effective diffusion of green technology innovation (Peng et al., 2020). Elements of the regional green technology innovation environment include socio-economic development, human resources, government funding, openness and so on. Especially as the environment becomes more complex, a single organization cannot handle all the tasks of a green innovation ecosystem, requiring multi-stakeholder collaborative innovation (Oliver et al., 2020). Green innovation alliances composed of industrial enterprises, universities and research institutions can coordinate human, technological and financial capital (Etzkowitz, 2003; Bartlett and Trifilova, 2010; Zygiaris, 2013), Share investment costs and $\mathrm{R} \& \mathrm{D}$ risks associated with socioeconomic uncertainty (Fernando and Wah, 2017). In China, a growing number of enterprises, universities and research institutions are joining alliances to achieve sustainability and gain a competitive advantage over other countries (Lin et al., 2020).

More importantly, government policies also make a significant contribution to green technology innovation relative to enterprise and environmental factors. Green technology enterprises generally face higher risks, such as increased innovation costs, funding challenges, and technology spillovers. Government policies can overcome the above-mentioned "market failure." Governments use green patents to protect the rights and interests of each green technology innovation subject. At the same time, governments can provide support policies, such as financial and tax incentives, market risk sharing, to cultivate and strengthen the ability of green technology innovation subjects (Guo et al., 2019). Furthermore, policies supporting green technology innovation can also strengthen the market expectations (Yuan and Zhang, 2020). In addition, governments popularize the concept of 
sustainable development, increase public awareness of green consumption, and improve the sense of corporate social responsibility in green technology innovation.

To some degree, the number of policies may reflect the degree of government attention on green technology innovation (Ren, 2020). Governance usually enacts some policies to respond to current important issues, known as the "campaign-style" policy (Bao et al., 2013). Therefore, the more policies promulgated each year, the stronger the signal to green technology innovation enterprises.

Government policies also tend to have cumulative effects, once a policy has been enacted, it will remain in effect until it is repealed. Zhang et al. (2021) proved that despite a policy can play a significant role in the first year after promulgation, it will have a lag effect, and the society needs some time to gradually adapt to the policy. Therefore, the impact of policy on green technology innovation will be greater in year two or year three than year one. Bao et al. (2013) found that legislation could achieve significant environmental improvement effects, and this effect would still exist even 2 years after legislation, but as time goes on, the effectiveness of previous policies would gradually weaken. Li et al. (2020) pointed out that the influence of government policy on green technology progress in Shandong Province will continue to be evident in the near future during the reform phase. Given what has been mentioned above, we propose the first hypothesis:

Hypothesis 1 (H1). Government policy has a promoting effect on green technology innovation.

Due to the difference of policy promulgation agencies and legal effect, the performance of government policy on green technology innovation is not consistent. The higher level of the institution, the more authoritative the policy is. This can be called policy effectiveness. The lower level of policy promulgation is, the lower the effectiveness will be, but it is easy to carry out specific work. This can be called policy executive force (Ma and Kong, 2017). Generally speaking, policies with high effectiveness have strong restraining and guiding effects (Zhang et al., 2016). Local government at a lower level can provide attainable financial and technological support to green technology innovation enterprises, according to the guidance of higher-level government (Wang et al., 2003; Wang and Jin, 2007). Besides, local governments at a lower level can decide how to implement the policies in the next step. Because various provinces may have different interest pursuits in terms of green technology innovation, so they have different choices in the policy quantity, policy effectiveness, and policy executive force. The second hypothesis is:

Hypothesis 2 (H2). Policy quantity, policy effectiveness and policy executive force can all promote green technology innovation, and the effect of policy quantity, policy executive force and policy effectiveness is different.

Government policies can convince enterprise decision-makers of the prospects of green technology innovation by increasing the attention of government (Shen et al., 2020). Government policies can broaden the marketplace for green technology products by increasing corporate responsibility and public awareness of green consumption. So, the role of enterprise innovation vitality in promoting green technology innovation can be improved if there is focused policy support and a perfect industrial development environment. However, some researches point environmental regulation policies have shown to restrain the efficiency of technological innovation and reduce enterprise productivity in some empirical analyses (Ramanathan et al., 2010; Leeuwen and Mohnen, 2013). Liu et al. (2020) also suggested that government subsidy policy would cause "crowding effect" which could hinder enterprises from carrying out green technology innovation activities. And even with some support policies, enterprises have increased their vitality and capacity to produce more new products. But in the absence of more targeted green technology innovation policies, enterprises may concentrate more on new technologies and products that generate economic benefits. The role of enterprise innovation vitality in the promotion of green technology innovation will be reduced.

In China, it is true that some policies aimed at improving enterprise innovation vitality, achieving green and low-carbon development and transformation have been implemented. But there are not many policies connecting the green development and enterprise innovation development, and fewer high effectiveness policies and concrete implementation policies. "Guidance on Building a Market-Oriented Green Technology Innovation System" enacted by the National Ministry was also just promulgated in 2020. It can also lead to enterprises, while receiving policy support and strengthening their innovation vitality, not applying more resources to green technology innovation. They spent more resources on other aspects of improving economic benefits. Another reason is that some enterprises rely too much on government support and do not focus on improving the efficiency of transforming their vitality into green technological innovation in some regions. The third hypothesis is:

Hypothesis 3 (H3). At the current stage, government policies may weaken rather than improve the role of enterprise innovation vitality in promoting green technology innovation. Figure 1 illustrates the theoretical framework for this paper.

\section{RESEARCH METHODOLOGY}

As mentioned in the introduction, China's green technology innovation is more important to its own sustainability and to the world. Furthermore, provincial regions in China have different characteristics for developing green technology innovation. Therefore, this study analyses the impact of government policies on green technology innovation in China's provincial regions and hopes to bring some references and enlightenments for other regions.

Based on theoretical analysis and hypotheses, this study first considered that enterprise innovation vitality is one enterprise factor which have a significant impact on green technology innovation. Then we added policy quantity, policy effectiveness and policy executive force respectively to explore the direct effect of government policy on green technology innovation. These models can be baseline model. In contrast, we also examine the effect of enterprise innovation vitality on 


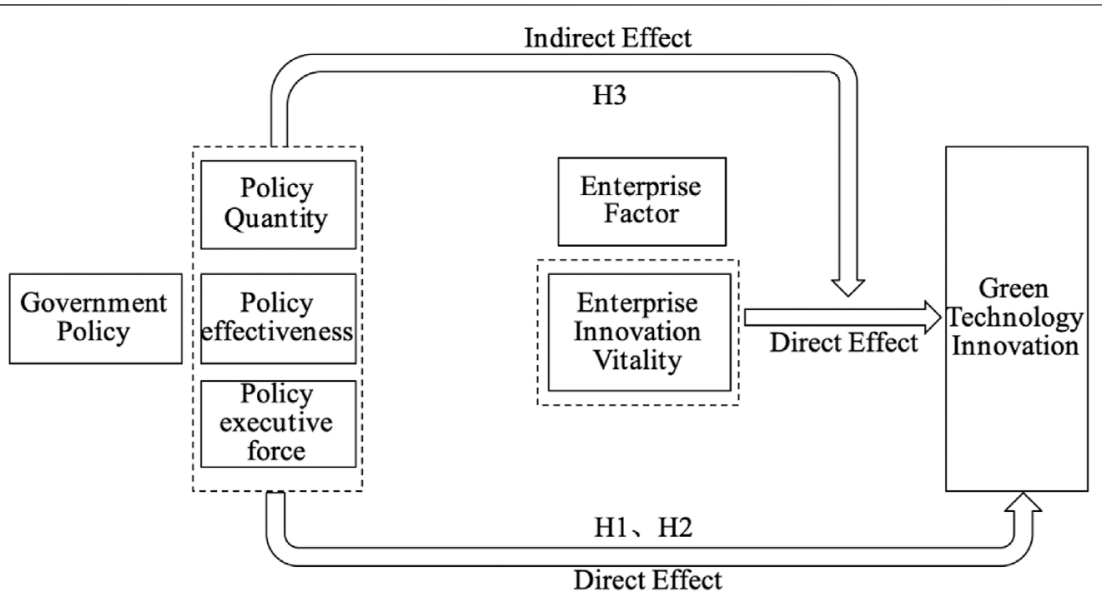

FIGURE 1 | Theoretical framework.

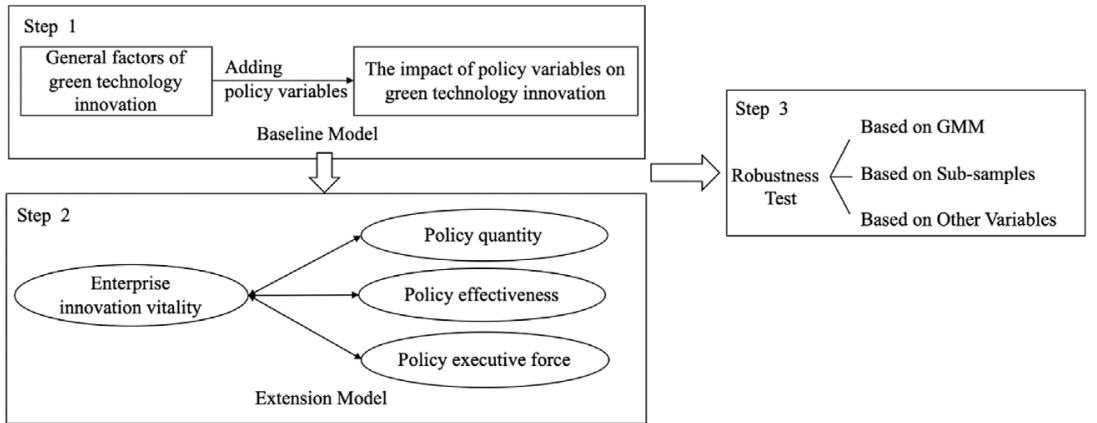

FIGURE 2 | Flowchart of research methodology.

green technology innovation when there are no policy variables in the baseline model. Second, we constructed extension models to explore the interaction between government policy variables and enterprise innovation vitality, which can verify the indirect effect of government policy on green technology innovation. Third, we use three different methods to test the robustness of baseline and extension models. Overall, the flowchart of research methodology is shown in Figure 2.

\section{Data Sources}

Since 2010, the government has gradually shifted its focus to green technology innovation policies, the number of green patents has also improved significantly (Wang and Zhao, 2019). And data on green patent applications have not been fully disclosed in the last 2 years. Therefore, the study period is from 2010 to 2019.

Green patent applications were collected with reference to the IPC Green Inventory published by the World Intellectual Property Organization (WIPO). The number of green patent applications was from the website of the State Intellectual Property Office. This paper manually collects policy about green technology innovation from the database of "PKU Law," which is a one-stop search platform, providing intelligent legal information and was built by the Law Department of Peking University in 1985. "PKU Law" is the most professional and comprehensive legal information retrieval system in China to date. This paper used the keywords "green," "patent," "science and technology," "technology" to retrieve policy documents from each province and collected 12,519 policies. 8,721 policies were selected finally through checking the contents and full texts. Other data comes from the China Science and Technology Statistical Yearbook and the National Bureau of Statistics.

\section{Empirical Model \\ Baseline Model}

Fixed effect (FE) model is often used for empirical analysis as it can solve the endogeneity problem (Wintoki et al., 2012; Guo et al., 2018). We also use FE model to explore the mechanism of government policy affecting green technology innovation. All variables in the model were analyzed by logarithmic substitution, which is used to reduce the heteroscedasticity of the equation and the multicollinearity of variables. We first 
construct the Model (1) to test the impact of enterprise factors on green technology innovation.

$$
\ln (\text { gpa })_{\text {it }}=a+\gamma \ln (\text { eiv })_{\text {it }}+\text { Control }_{\text {it }}+\mathrm{u}_{\mathrm{it}}+\varepsilon_{\mathrm{it}}
$$

In Model (1), The subscript $\mathrm{i}$ represents the province and $\mathrm{t}$ represents the year. Variable gpa represents the number of green patent applications. Variable eiv refers to enterprise innovation vitality. Variable Control is a set of control variables, including industry-university-research cooperation (iurc), the degree of fiscal attention (fad), the degree of openness (oe), technology environment (te), economic development (gdp). Variable $\alpha$ is the constant term, $\mathrm{u}_{\mathrm{it}}$ is the individual effect, and $\varepsilon_{i t}$ is the error term. $\gamma$ represents the estimated coefficient set of enterprise factors.

Meanwhile, since our main objective is the impact of policy variables, we add policy quantity, policy effectiveness and policy executive force respectively to analyze the effect of policy variables on green technology innovation on the basis of Model (1).

$\ln (\mathrm{gpa})_{\mathrm{it}}=\alpha+\beta \ln (\mathrm{PV})_{\mathrm{it}}+\gamma \ln (\mathrm{eiv})_{\mathrm{it}}+$ Control $_{\mathrm{it}}+\mathrm{u}_{\mathrm{it}}+\varepsilon_{\mathrm{it}}$

In Model (2), PV is a variable set of policy variables containing green technology innovation policy quantity (pq), policy effectiveness (ge) and policy executive force (gz). $\beta$ is the estimated coefficient set of policy variables.

\section{Extension Model}

Based on Model (2), this study further examines the combination impact of policy variables and enterprise factors on green technology innovation:

$$
\begin{aligned}
\ln (\mathrm{gpa})_{\mathrm{it}}= & \alpha+\beta \ln (\mathrm{PV})_{\mathrm{it}}+\gamma \ln (\mathrm{eiv})_{\mathrm{it}}+\varphi \overline{\mathrm{PV}_{\mathrm{it}} \times \mathrm{eiv}_{\mathrm{it}}} \\
& + \text { Control }_{\mathrm{it}}+\mathrm{u}_{\mathrm{it}}+\varepsilon_{\mathrm{it}}
\end{aligned}
$$

In Model (3), $\overline{P V_{i t} \times e^{i v} v_{i t}}$ express the interaction terms of policy variables with enterprise innovation vitality, and $\varphi$ is the coefficient set of interaction terms.

\section{GMM Model}

Finally, although many factors have been controlled, there may still be a concern about endogeneity because of missing variables, simultaneity or measurement errors. Consequently, to ensure the robustness of the empirical analysis results, this paper should test the robustness of the model. Robustness test mainly includes the following methods: instrumental variable method, using alternative variables, using new data and using other estimation methods. Since effective instrumental variables cannot be obtained in this paper, we use system GMM (Generalized Moment method) as the alternative estimation methods, using sub-samples as the new data and using alternative variables to test the robustness of the results of fixed effect (FE) model. The advantage of GMM is that it is a good method to alleviate the endogeneity problem of panel data, which is very suitable for short panel data and is widely used in the empirical analysis; however, the disadvantage of GMM is that it excludes individual and time effects. (Wintoki et al., 2012; Qian et al., 2018). The lag variable of green technology innovation is added into the system GMM, and the specific models are as follows:

$$
\begin{aligned}
\ln (\mathrm{gpa})_{\mathrm{it}}=\alpha & +\partial_{1} \ln (\mathrm{gpa})_{\mathrm{i}(\mathrm{t}-1)}+\gamma \ln (\text { eiv })_{\mathrm{it}}+\operatorname{Control}_{\mathrm{it}}+\mathrm{u}_{\mathrm{it}} \\
+ & \varepsilon_{\mathrm{it}} \\
\ln (\mathrm{gpa})_{\mathrm{it}}= & \alpha+\partial_{2} \ln (\mathrm{gpa})_{\mathrm{i}(\mathrm{t}-1)}+\beta \ln (\mathrm{PV})_{\mathrm{it}}+\gamma \ln (\text { eiv })_{\mathrm{it}} \\
& +\operatorname{Control}_{\mathrm{it}}+\mathrm{u}_{\mathrm{it}}+\varepsilon_{\mathrm{it}} \\
\ln (\mathrm{gpa})_{\mathrm{it}}= & \alpha+\partial_{3} \ln (\mathrm{gpa})_{\mathrm{i}(\mathrm{t}-1)}+\beta \ln (\mathrm{PV})_{\mathrm{it}}+\gamma \ln (\mathrm{eiv})_{\mathrm{it}} \\
& +\varphi \overline{\mathrm{PV}}_{\mathrm{it}} \times \text { eiv }_{\mathrm{it}}+\operatorname{Control}_{\mathrm{it}}+\mathrm{u}_{\mathrm{it}}+\varepsilon_{\mathrm{it}}
\end{aligned}
$$

\section{Variable Description and Descriptive Statistics}

\section{Dependent variable}

Based on previous research (Wang and Chu, 2019; Deng and Chen, 2020; Gong et al., 2020), this paper uses the number of green patent applications (gpa) to indicate green technology innovation. The main reason is that green patent application data can reflect green technology innovation more directly (Evenson and Griliches, 1990; Haščič and Migotto, 2015).

\section{Independent variables}

Green technology innovation policy quantity (pq): This paper adopts the sum of comprehensive policy quantity in the current research period and the research base period. It would better reflect the cumulative effect of the policy. The scope of policy be counted include all relevant green technology innovation policy tools such as finance, taxation, and environmental regulation etc., avoiding the policy covers too one-sided content.

Green technology innovation policy effectiveness (ge) and green technology innovation policy executive force (gz): Referring to the research of Peng et al. (2008), Zhang et al. (2016), Wang and Zou (2018) and the official recognition standard of "PKU Law." We set out policy promulgated by various local departments at three different levels in this paper: Local laws and regulations, Normative documents promulgated (Views, Outline, Planning, Methods, Interim Provisions), Working papers (Notices, Announcements). Because our study field is at the provincial level, laws and regulations promulgated by National Congress and National Ministerial decree of the departments are not considered.

TABLE 1 | Policy Point.

\section{Policy}

Policy effectiveness

Policy executive force

Local laws and regulations Normative documents Working papers

$\begin{array}{ll}3 & 1 \\ 2 & 2 \\ 1 & 3\end{array}$


TABLE 2 | Variables description.

\begin{tabular}{|c|c|c|c|}
\hline Variable type & Variable name & Notation & Indicators \\
\hline $\begin{array}{l}\text { Dependent } \\
\text { Variable (gpa) }\end{array}$ & Green technology innovation & gpa & Green patent applications \\
\hline \multirow[t]{3}{*}{ Policy Variables (PV) } & Policy quantity & $p q$ & Quantity of green technology innovation policy \\
\hline & Policy effectiveness & ge & Score of green technology innovation policy effectiveness \\
\hline & Policy executive force & $g z$ & Score of green technology innovation policy executive force \\
\hline \multirow[t]{2}{*}{ Enterprise Factors (eiv) } & Enterprise innovation vitality & eiv & Sales revenue of new products of industrial enterprises \\
\hline & $\begin{array}{l}\text { Industry-university-research } \\
\text { cooperation }\end{array}$ & iurc & $\begin{array}{l}\text { The sum of the investment in research institutes and universities of industrial enterprises' R\&D } \\
\text { external expenditures }\end{array}$ \\
\hline \multirow[t]{4}{*}{$\begin{array}{l}\text { Control Variables } \\
\text { (Control) }\end{array}$} & The degree of fiscal attention & fad & $\begin{array}{l}\text { Local finance expenditure on science, technology and environment/local finance expenditure in } \\
\text { general budget }\end{array}$ \\
\hline & The degree of openness & oe & Foreign direct investment \\
\hline & Technology environment & te & Employees of environment and science and technology units \\
\hline & Economic development & $g d p$ & Per capita GDP \\
\hline
\end{tabular}

TABLE 3 | Descriptive statistics.

Variables
Green patent applications
Policy quantity
Enterprise innovation vitality
Industrial-university-research cooperation
The degree of fiscal attention
The degree of openness
Technology environment
Economic development

Notation
gpa
pq
eiv
iurc
fad

$\begin{array}{ccccc}\mathbf{N} & \text { Min } & \text { Max } & \text { Mean } & \text { Std. Dev } \\ 300 & 51 & 68413 & 8145.880 & 11340.676 \\ 300 & 1 & 725 & 144.750 & 142.827 \\ 300 & 0.857 & 4297.006 & 493.815 & 689.631 \\ 300 & 17.320 & 19672.130 & 987.989 & 1930.605 \\ 300 & 210.190 & 1201.841 & 507.505 & 163.777 \\ 300 & 23.490 & 19532.520 & 1632.449 & 2671.177 \\ 300 & 22 & 839 & 205.940 & 141.842 \\ 300 & 131.190 & 1642.200 & 525.696 & 264.489\end{array}$

Their effectiveness relationship is illustrated as follows: Local laws and regulations $>$ Normative documents $>$ Working papers, and their executive force relationship is illustrated as follows: Working papers > Normative documents > Local laws and regulations.

The calculation formula and the policy points are shown in Eqs 7, 8 and Table 1 .

$$
\begin{aligned}
& \text { ge }_{\text {it }}=\operatorname{gtip}_{\text {it }} 1 \times 3+\operatorname{gtip}_{\mathrm{it}} 2 \times 2+\operatorname{gtip}_{\mathrm{it}} 3 \times 1 \\
& \mathrm{gz}_{\mathrm{it}}=\operatorname{gtip}_{\mathrm{it}} 1 \times 1+\operatorname{gtip}_{i t} 2 \times 2+\text { gtip }_{\mathrm{it}} 3 \times 3
\end{aligned}
$$

gtip $p_{i t} 1, g t i p_{i t} 2$ and $g t i p_{i t} 3$ respectively represents the green technology innovation policy number of local laws and regulations, normative documents, and working papers of $i$ province in the $t$ year.

Enterprise innovation vitality (eiv): Measured by the new product sales revenue of industrial enterprises (Hu et al., 2019; Zhang, 2019).

\section{Control variables}

Industry-university-research cooperation (iurc): Measured by the sum of the investment in research institutes and universities of industrial enterprises' R\&D external expenditures (Fang and Chiu, 2017; Qian et al., 2018).

The degree of fiscal attention (fad): Measured by the ratio of local fiscal expenditure on science, technology and environment and local fiscal expenditure on general budget (Wang and Chu, 2019).
The degree of openness (oe): Represented by the foreign direct investment in various provinces (Sheng and Zhou, 2018; Xiao et al., 2018).

Technology environment (te): Expressed by employees of science and technology and environment units in various provinces (Wu and You, 2019; Xu et al., 2019).

Economic development (gdp): The economic development in various provinces is measured by the per capita GDP (Guo et al., 2018; Wang et al., 2019; Zhang, 2019). Table 2 shows all the variables in this paper.

The descriptive statistics of all variables are shown in Table 3.

\section{RESULTS AND DISCUSSION}

\section{Model Test}

We select policy quantity in three policy variables and all other variables to perform the correlation test and the multicollinearity test. Correlation analysis results show that all explanatory variables are significantly correlated with the explained variables. The VIF values of the multicollinearity test are all less than 10, indicating that variables in this study are independent of each other and that the results of parameter estimation are reliable.

Since the data in this paper belongs to short panel data with cross-sectional variable $\mathrm{N}(\mathrm{N}=30)$ greater than time-series $\mathrm{T}(\mathrm{T}=$ 10 ), this study used the mixed ordinary least squares (OLS) 
TABLE 4 | Baseline results.

\begin{tabular}{|c|c|c|c|c|c|c|c|c|}
\hline \multirow[t]{2}{*}{ Variable } & \multicolumn{2}{|c|}{ Model (1) } & \multicolumn{2}{|c|}{ Model (2-1) } & \multicolumn{2}{|c|}{ Model (2-2) } & \multicolumn{2}{|c|}{ Model (2-3) } \\
\hline & (a) & (b) & (a) & (b) & (a) & (b) & (a) & (b) \\
\hline eiv & $\begin{array}{c}0.500^{\star \star \star} \\
(0.000)\end{array}$ & $\begin{array}{c}0.302^{\star \star \star} \\
(0.000)\end{array}$ & $\begin{array}{c}0.355^{\star \star \star} \\
(0.000)\end{array}$ & $\begin{array}{c}0.298^{\star \star \star} \\
(0.000)\end{array}$ & $\begin{array}{c}0.365^{\star \star \star} \\
(0.000)\end{array}$ & $\begin{array}{c}0.301^{\star \star \star} \\
(0.000)\end{array}$ & $\begin{array}{c}0.362^{\star \star \star} \\
(0.000)\end{array}$ & $\begin{array}{c}0.298^{\star \star \star} \\
(0.000)\end{array}$ \\
\hline$p q$ & & & $\begin{array}{c}0.318^{\star \star \star} \\
(0.000)\end{array}$ & $\begin{array}{c}0.299^{\star \star \star} \\
(0.000)\end{array}$ & & & & \\
\hline ge & & & & & $\begin{array}{c}0.321^{\star \star \star} \\
(0.000)\end{array}$ & $\begin{array}{c}0.302^{\star \star \star} \\
(0.000)\end{array}$ & & \\
\hline$g z$ & & & & & & & $\begin{array}{c}0.292^{\star \star \star} \\
(0.000)\end{array}$ & $\begin{array}{c}0.284^{\star \star \star} \\
(0.000)\end{array}$ \\
\hline time effect & No & Yes & No & Yes & No & Yes & No & Yes \\
\hline$N$ & 300 & 300 & 300 & 300 & 300 & 300 & 300 & 300 \\
\hline Model & FE & $\mathrm{FE}$ & FE & FE & FE & FE & FE & $\mathrm{FE}$ \\
\hline$R^{2}$ & 0.890 & 0.942 & 0.926 & 0.944 & 0.925 & 0.944 & 0.925 & 0.944 \\
\hline
\end{tabular}

Note: Numbers in brackets denote $\mathrm{p}$ values; ${ }^{* * *},{ }^{* *}$ or ${ }^{*}$ denotes significance at the level of 1,5 or $10 \%$, respectively; control variables' results are omitted.

regression, clustering robust standard error mixed OLS regression, least squares dummy variable (LSDV) method, and random effects model regression to test the applicability of fixed effect (FE) model. After a series of tests, the final results show that the fixed effect (FE) model is very suitable for the data in this paper, so this paper eventually uses the fixed effect (FE) model for regression analysis.

\section{Baseline Results}

Models (1) (2-1) (2-2) and (2-3) in Table 4 shows the empirical analysis results of baseline Models (1) and (2), column (a) in each Model are the results that only individual effects are controlled, column (b) in each Model are the results of fixed effect (FE) model that both individual effects and time effects are controlled. Results in column (a) of Model (1) show that the coefficient of eiv is 0.500 with a statistical significance of $1 \%$. It suggests that when time effects are not considered, enterprise innovation vitality can significantly enhance green technology innovation. Results in column (b) of Model (1) show that after control the time effect, the promoting effect of enterprise innovation vitality is still significant and just declined.

As our main focus in the study, the results in Models (2-1) $(2-2)(2-3)$ indicate that policy variables have a positive direct impact on green technology innovation. The coefficients of pq, ge, and gz in column (a) are respectively $0.318,0.321$, and 0.292 with a statistical significance of $1 \%$; and the coefficients of pq, ge, and gz in column (b) are respectively $0.299,0.302$, and 0.284 with a statistical significance of $1 \%$. Meanwhile, it can also be seen that there is little difference between the coefficients of policy quantity and policy effectiveness, while both of them are larger than the coefficient of policy executive force. It indicates that the direct promoting effect of policy executive force on green technology innovation is slightly weaker than that of policy quantity and policy effectiveness. However, comparing the results of column (a) to those of column (b) in Models (2-1) $(2-2)(2-3)$, the coefficients of all variables after adding a time effect are lower than the coefficients of all variables before. The $\mathrm{R}^{2}$ values is larger when time effect is controlled. It is suggested that the impact of all variables on green technology innovation may be over-estimated before adding a time effect. Subsequent

\begin{tabular}{lccc}
\hline TABLE 5 | Extension results. & & \\
\hline Variable & Model (3-1) & Model (3-2) & Model (3-3) \\
\hline$\overline{p q \times e i v}$ & $-0.062^{\star \star \star}$ & & \\
& $(0.000)$ & & \\
\hline$g e \times$ eiv & & $-0.064^{\star \star \star}$ & \\
& & $(0.000)$ & $-0.060^{\star \star \star}$ \\
\hline$g z \times$ eiv & & & $(0.000)$ \\
time effect & Yes & Yes & Yes \\
$N$ & 300 & 300 & 300 \\
Model & $\mathrm{FE}$ & $\mathrm{FE}$ & $\mathrm{FE}$ \\
$R^{2}$ & 0.949 & 0.949 & 0.949 \\
\end{tabular}

Note: Numbers in brackets denote $\mathrm{p}$ values; ***, ** or * denotes significance at the level of 1,5 or $10 \%$, respectively; other variables' results are omitted.

\begin{tabular}{lcccc}
\hline \multicolumn{4}{l}{ TABLE 6 } & Baseline results of GMM. \\
\hline Variable & Model (4) & Model (5-1) & Model (5-2) & Model (5-3) \\
\hline L.gpa & $0.977^{\star \star \star}$ & $0.498^{\star \star \star}$ & $0.512^{\star \star \star}$ & $0.907^{\star \star \star}$ \\
& $(0.000)$ & $(0.000)$ & $(0.000)$ & $(0.000)$ \\
eiv & $0.112^{\star \star}$ & $0.209^{\star \star \star}$ & $0.218^{\star \star \star}$ & $0.201^{\star \star \star}$ \\
& $(0.011)$ & $(0.000)$ & $(0.000)$ & $(0.000)$ \\
pq & & $0.292^{\star \star \star}$ & & \\
ge & $(0.000)$ & & \\
& & & $0.292^{\star \star \star}$ & \\
gz & & & $(0.000)$ & \\
& & & & $0.280^{\star \star \star}$ \\
N & & & & $(0.000)$ \\
Model & GMM & GMM & GMM & GMM
\end{tabular}

Note: Numbers in brackets denote $\mathrm{p}$ values; ${ }^{* * *},{ }^{* *}$ or ${ }^{*}$ denotes significance at the level of 1,5 or $10 \%$, respectively; control variables' results are omitted.

analyses are therefore developed using models controlling time effects.

\section{Extension Results}

Another focus in this study is the indirect effect of policy variables on green technology innovation. Table 5 shows that the model results (3-1) (3-2) and (3-3) were obtained using the fixed effect 
TABLE 7 | Extension results of GMM

\begin{tabular}{lccc}
\hline Variable & Model (6-1) & Model (6-2) & Model (6-3) \\
\hline$\overline{p q \times \text { eiv }}$ & $-0.031^{\star}$ & & \\
$\overline{g e \times \text { eiv }}$ & $(0.072)$ & & \\
$\overline{g z \times \text { eiv }}$ & & $-0.034^{* \star}$ & \\
$N$ & & $(0.043)$ & $-0.030^{*}$ \\
Model & & & $(0.095)$ \\
& GMM & 270 & 270 \\
Geto: & GMM & GMM
\end{tabular}

Note: Numbers in brackets denote p values; ${ }^{* * *},{ }^{* *}$ or ${ }^{*}$ denotes significance at the level of 1,5 or $10 \%$, respectively; other variables' results are omitted.

(FE) model controlling the time effect. The coefficients of the interaction term between policy variables and enterprise innovation vitality are respectively $-0.062,-0.064$ and -0.060 with a statistical significance level of $1 \%$. The results suggest that the policy quantity, policy effectiveness and policy executive force can all inhibit the promoting effect of enterprise innovation vitality on green technology innovation.

\section{Robustness Test}

\section{Robustness Test Based on GMM}

This paper re-estimates the coefficients of parameters using systematic GMM estimation based on Models 4-6, the empirical results are shown in Tables 6, 7.

Comparing results in Table 4 with results in Table 6, it is found that baseline results of systematic GMM regression and fixed effect (FE) model adding time effect are basically consistent. The coefficient of pq changed from 0.299 to 0.292 , the coefficient of ge changed from 0.302 to 0.292 , the coefficient of gz changed from 0.284 to 0.280 . All three coefficients are significant at $1 \%$ level. The promoting effect of policy executive force on green technology innovation is still slightly weaker than that of policy quantity and policy effectiveness. Furthermore, the first-stage lag term coefficients of green technology innovation are all positive with a statistical significance of $1 \%$. This is consistent with the results in the study of Chen et al. (2019), which indicates that current green technology innovation and related policy system require a long period of time to develop due to the technical difficulties and uncertain market prospect.

By comparing the results of extension model with systematic GMM estimation in Table 7 to the results of extension model in Table 5, it can be found that the influence degree and direction of interaction term between policy variables and enterprise innovation vitality are generally consistent. All three coefficients of interaction term in systematic GMM estimation Model are slightly lower than those in fixed effect (FE) extension model. The level of significance is a bit lower.

\section{Robustness Test Based on Sub-Samples}

The previous results are based on regression of overall provincial panel data. But the eastern, middle and western regions have different socioeconomic characteristics and technological innovation development environment in China. In order to check the consistency of the effect of the various regional policy variables on green technology innovation, we carried out robustness test analysis with the eastern, middle and western provincial data. Robustness tests were performed using the fixed effect (FE) model adding time effect. This can also be served as heterogeneity test, which makes the research more in-depth.

There we only report the results of core Models, namely Model (2) and Model (3). The coefficients of policy quantity on green technology innovation in eastern, middle and western regions are respectively $0.265,0.363$ and 0.346 ; the coefficients of policy effectiveness on green technology innovation in eastern, middle and western regions are 0.263, 0.412 and 0.381, respectively; the coefficients of policy executive force on green technology innovation in eastern, middle and western regions are $0.243,0.325$ and 0.315 , respectively. All the coefficients are significant at the statistical level of $1 \%$. The results show that policy variables indeed have a nonnegligible promoting effect on green technology innovation.

Based on the results in Table 8, the promoting effect of policy variables on green technology innovation in the middle region is the highest, then is the western region, and the eastern region. For eastern region, there is no obvious difference in the effect of policy quantity and policy effectiveness on green technology innovation, but the coefficient of policy executive force is slightly smaller than those of policy quantity and policy effectiveness. The result is consistent with the provincial empirical results in Tables 4, 6. For middle and western regions, the difference of coefficients among policy variables is obvious. The coefficient of policy effectiveness on green technology innovation are greater than coefficients of policy quantity and policy executive force. The coefficients of policy executive force are the smallest.

The empirical results in Table 9 further demonstrates the interaction effects of policy variables and enterprise factors on green technology innovation. The interaction term coefficients of pq, ge, gz and eiv in the eastern region are respectively -0.031 , -0.040 and -0.024 , only the coefficient of $\overline{g e} \times$ eiv is significant. The interaction term coefficients of pq, ge, gz and eiv in the middle region are respectively $0.069,0.068$ and 0.067 with a statistical significance of $5 \%$. The interaction term coefficients of $\mathrm{pq}, \mathrm{ge}, \mathrm{gz}$ and eiv in the western region are $-0.047,-0.051$ and -0.045 at a significance level around 5\%. It suggests that policy variables in the middle regions can promote the positive impact of enterprise innovation vitality on green technology innovation, policy variables in the west regions can inhibit the positive impact of enterprise innovation vitality on green technology innovation, but the policy variables do not affect the effect of enterprise innovation vitality on green technology innovation in the east region.

\section{Robustness Test Based on Other Variables}

For further robustness testing, this paper replaces the measurements of dependent variable and the independent variable to re-estimate, respectively.

Because green patent includes green invention patent and green utility model patent, this paper uses green invention patents and green utility model patents as the new dependent variable. The results are respectively shown in column (m1) and column 
TABLE 8 | Baseline results of Model (2).

\begin{tabular}{|c|c|c|c|c|c|c|c|c|c|}
\hline \multirow[t]{2}{*}{ Variable } & \multicolumn{3}{|c|}{ Model (2-1) } & \multicolumn{3}{|c|}{ Model (2-2) } & \multicolumn{3}{|c|}{ Model (2-3) } \\
\hline & East & Middle & West & East & Middle & West & East & Middle & West \\
\hline$p q$ & $\begin{array}{c}0.265^{\star \star \star} \\
(0.000)\end{array}$ & $\begin{array}{c}0.363^{\star \star \star} \\
(0.000)\end{array}$ & $\begin{array}{c}0.346^{\star \star \star} \\
(0.000)\end{array}$ & & & & & & \\
\hline ge & & & & $\begin{array}{c}0.263^{\star \star \star} \\
(0.000)\end{array}$ & $\begin{array}{c}0.412^{\star \star \star} \\
(0.000)\end{array}$ & $\begin{array}{c}0.381^{\star \star \star} \\
(0.000)\end{array}$ & & & \\
\hline$g z$ & & & & & & & $\begin{array}{c}0.243^{\star \star \star} \\
(0.000)\end{array}$ & $\begin{array}{c}0.325^{\star \star \star} \\
(0.000)\end{array}$ & $\begin{array}{c}0.315^{\star \star \star} \\
(0.000)\end{array}$ \\
\hline eiv & $\begin{array}{c}0.234^{\star \star \star} \\
(0.006)\end{array}$ & $\begin{array}{c}0.282^{\star \star \star} \\
(0.004)\end{array}$ & $\begin{array}{c}0.366^{\star \star \star} \\
(0.000)\end{array}$ & $\begin{array}{l}0.222^{\star \star} \\
(0.010)\end{array}$ & $\begin{array}{c}0.260^{\star \star \star} \\
(0.006)\end{array}$ & $\begin{array}{c}0.386^{\star \star \star} \\
(0.000)\end{array}$ & $\begin{array}{c}0.271^{\star \star \star} \\
(0.001)\end{array}$ & $\begin{array}{c}0.287^{\star \star \star} \\
(0.004)\end{array}$ & $\begin{array}{c}0.359^{\star \star \star} \\
(0.000)\end{array}$ \\
\hline time effect & Yes & Yes & Yes & Yes & Yes & Yes & Yes & Yes & Yes \\
\hline$N$ & 110 & 80 & 110 & 110 & 80 & 110 & 110 & 80 & 110 \\
\hline Model & FE & FE & FE & $\mathrm{FE}$ & FE & FE & FE & FE & $\mathrm{FE}$ \\
\hline$R^{2}$ & 0.965 & 0.964 & 0.947 & 0.964 & 0.964 & 0.947 & 0.966 & 0.965 & 0.946 \\
\hline
\end{tabular}

Note: Numbers in brackets denote $\mathrm{p}$ values; ${ }^{* *},{ }^{* *}$ or ${ }^{*}$ denotes significance at the level of 1,5 or $10 \%$, respectively; control variables' results are omitted.

TABLE 9 | Extension results of Model (3).

\begin{tabular}{|c|c|c|c|c|c|c|c|c|c|}
\hline \multirow[t]{2}{*}{ Variable } & \multicolumn{3}{|c|}{ Model (3-1) } & \multicolumn{3}{|c|}{ Model (3-2) } & \multicolumn{3}{|c|}{ Model (3-3) } \\
\hline & East & Middle & West & East & Middle & West & East & Middle & West \\
\hline$\overline{p q \times \text { eiv }}$ & $\begin{array}{l}-0.031 \\
(0.118)\end{array}$ & $\begin{array}{l}0.069^{\star \star} \\
(0.034)\end{array}$ & $\begin{array}{c}-0.047^{\star \star} \\
(0.049)\end{array}$ & & & & & & \\
\hline$\overline{g e \times e i v}$ & & & & $\begin{array}{c}-0.040^{*} \\
(0.056)\end{array}$ & $\begin{array}{l}0.068^{\star \star} \\
(0.037)\end{array}$ & $\begin{array}{c}-0.051^{\star \star} \\
(0.039)\end{array}$ & & & \\
\hline$\overline{g z \times e i v}$ & & & & & & & $\begin{array}{r}-0.024 \\
(0.235)\end{array}$ & $\begin{array}{l}0.067^{\star \star} \\
(0.040)\end{array}$ & $\begin{array}{c}-0.045^{\star} \\
(0.054)\end{array}$ \\
\hline time effect & Yes & Yes & Yes & Yes & Yes & Yes & Yes & Yes & Yes \\
\hline$N$ & 110 & 80 & 110 & 110 & 80 & 110 & 110 & 80 & 110 \\
\hline Model & FE & FE & FE & FE & FE & FE & FE & $\mathrm{FE}$ & FE \\
\hline$R^{2}$ & 0.966 & 0.967 & 0.952 & 0.966 & 0.968 & 0.953 & 0.966 & 0.967 & 0.952 \\
\hline
\end{tabular}

Note: Numbers in brackets denote p values; ${ }^{* * *}{ }^{* *}$ or * denotes significance at the level of 1, 5 or 10\%, respectively; other variables' results are omitted.

TABLE 10 | Baseline results of Model (2).

\begin{tabular}{|c|c|c|c|c|c|c|c|c|c|}
\hline \multirow[t]{2}{*}{ Variable } & \multicolumn{3}{|c|}{ Model (2-1) } & \multicolumn{3}{|c|}{ Model (2-2) } & \multicolumn{3}{|c|}{ Model (2-3) } \\
\hline & $(\mathrm{m} 1)$ & (m2) & (n) & (m1) & (m2) & (n) & (m1) & (m2) & (n) \\
\hline$p q$ & $\begin{array}{c}0.284^{\star \star \star} \\
(0.000)\end{array}$ & $\begin{array}{c}0.348^{\star \star \star} \\
(0.000)\end{array}$ & $\begin{array}{c}0.111^{\star \star \star} \\
(0.000)\end{array}$ & & & & & & \\
\hline ge & & & & $\begin{array}{c}0.289^{\star \star \star} \\
(0.000)\end{array}$ & $\begin{array}{c}0.347^{\star \star \star} \\
(0.000)\end{array}$ & $\begin{array}{c}0.105^{\star \star \star} \\
(0.001)\end{array}$ & & & \\
\hline$g z$ & & & & & & & $\begin{array}{c}0.257^{\star \star \star} \\
(0.000)\end{array}$ & $\begin{array}{c}0.326^{\star \star \star} \\
(0.000)\end{array}$ & $\begin{array}{c}0.101^{\star \star \star} \\
(0.000)\end{array}$ \\
\hline eiv & $\begin{array}{c}0.342^{\star \star \star} \\
(0.000)\end{array}$ & $\begin{array}{c}0.318^{\star \star \star} \\
(0.000)\end{array}$ & $\begin{array}{c}0.471^{\star \star \star} \\
(0.000)\end{array}$ & $\begin{array}{c}0.349^{\star \star \star} \\
(0.000)\end{array}$ & $\begin{array}{c}0.330^{\star \star \star} \\
(0.000)\end{array}$ & $\begin{array}{c}0.476^{\star \star \star} \\
(0.000)\end{array}$ & $\begin{array}{c}0.350^{\star \star \star} \\
(0.000)\end{array}$ & $\begin{array}{c}0.322^{\star \star \star} \\
(0.000)\end{array}$ & $\begin{array}{c}0.471^{\star \star \star} \\
(0.000)\end{array}$ \\
\hline time effect & Yes & Yes & Yes & Yes & Yes & Yes & Yes & Yes & Yes \\
\hline$N$ & 300 & 300 & 300 & 300 & 300 & 300 & 300 & 300 & 300 \\
\hline Model & FE & $\mathrm{FE}$ & FE & FE & FE & FE & FE & FE & FE \\
\hline$R^{2}$ & 0.920 & 0.939 & 0.942 & 0.920 & 0.938 & 0.942 & 0.920 & 0.941 & 0.942 \\
\hline
\end{tabular}

Note: Numbers in brackets denote p values; ${ }^{* *},{ }^{* *}$ or * denotes significance at the level of 1, 5 or 10\%, respectively; control variables' results are omitted.

(m2) of Tables 10, 11. The results in Table $\mathbf{1 0}$ are basically the same as the results of Model (2) in Table 4. We analyze using current period policy data instead of a combination of previous periods policy and current period policy data. The results are shown in column (n) of Tables 10, 11. It can be found that all policy variables have a positive impact on green technology innovation, but these positive effects are smaller than those of cumulative policies for green technology innovation.

The interaction term coefficients of policy variables and eiv in column (m2) of Table $\mathbf{1 1}$ show that policy quantity and policy effectiveness reduce the positive effect of enterprise innovation vitality on green utility model patents. The results in column (n) 


\begin{tabular}{|c|c|c|c|c|c|c|c|c|c|}
\hline \multirow[t]{2}{*}{ Variable } & \multicolumn{3}{|c|}{ Model (3-1) } & \multicolumn{3}{|c|}{ Model (3-2) } & \multicolumn{3}{|c|}{ Model (3-3) } \\
\hline & (m1) & (m2) & (n) & (m1) & (m2) & (n) & (m1) & (m2) & (n) \\
\hline$\overline{p q \times e i v}$ & $\begin{array}{l}-0.020 \\
(0.150)\end{array}$ & $\begin{array}{c}-0.116^{\star \star \star} \\
(0.000)\end{array}$ & $\begin{array}{l}-0.009 \\
(0.533)\end{array}$ & & & & & & \\
\hline$\overline{g e \times e i v}$ & & & & $\begin{array}{l}-0.020 \\
(0.155)\end{array}$ & $\begin{array}{c}-0.120^{\star \star \star} \\
(0.000)\end{array}$ & $\begin{array}{l}-0.010 \\
(0.476)\end{array}$ & & & \\
\hline time effect & Yes & Yes & Yes & Yes & Yes & Yes & Yes & Yes & Yes \\
\hline N & 300 & 300 & 300 & 300 & 300 & 300 & 300 & 300 & 300 \\
\hline Model & $\mathrm{FE}$ & $\mathrm{FE}$ & $\mathrm{FE}$ & $\mathrm{FE}$ & $\mathrm{FE}$ & $\mathrm{FE}$ & $\mathrm{FE}$ & FE & $\mathrm{FE}$ \\
\hline$R^{2}$ & 0.921 & 0.954 & 0.942 & 0.921 & 0.954 & 0.942 & 0.921 & 0.954 & 0.942 \\
\hline
\end{tabular}

Note: Numbers in brackets denote p values; ${ }^{* * *}$, ${ }^{* *}$ or * denotes significance at the level of 1, 5 or 10\%, respectively; other variables' results are omitted.

of Table 11 show that current policy variables have no obvious influence in the promoting effect of enterprise innovation vitality on green technology innovation.

\section{Discussion}

\section{The Direct Effect of Government Policy}

The direct effect of government policy is one of our interests in this paper. All the baseline results suggest that policy quantity, effectiveness and executive force can significantly promote green technology innovation. Now the government's policy support for green technology innovation is still in the stage of continuous improvement, and policy quantity, effectiveness and executive force are the main influencing factors. This is consistent with the findings of Wang and Zhao (2019), Yan and Wu (2020), and is contrary to the study of Pei et al. (2019), Yan and Wu (2020), and is contrary to the study of Pei et al. (2019). The difference may be due to the different policy proxy indicators used for analysis. The results of this paper show that more comprehensive policy can directly supports enterprises' green technology innovation. In recent years, government policies not only encourage green growth, but also public innovation in China. More and more research institutes, university, units and individuals are interested in green technology innovation. It is not enough to focus solely on the role of companies in green technology innovation. The policy environment is also very important in enhancing the regional level of green technology innovation. Hypothesis 1 is verified.

Furthermore, all the baseline results above show that policy quantity and effectiveness promote green technology innovation more than policy executive force. It may be because the sum of policies directly targeting green technology innovation is still few and not enough. The policy executive force is limited by policy quantity and effectiveness after all. Similarly, Wang et al. (2003) pointed out that to a certain extent, the policy implementation force itself is affected by the quantity and effectiveness of policies. Only when a policy is released can the lower-level departments implement it. The higher the policy department level, the more likely the local implementation department is to deliver on it. Hypothesis 2 is supported.

Through the analysis of sub-samples robustness test, we can find that policy has a greater effect on green technology innovation in the middle and western regions than in the eastern region. The reason may be that the economic level and technology level in the eastern region are higher than those of the middle and western regions, trend of green technology innovation can depend more on the overall environment and green technology innovation enterprise. Of course, the eastern region still needs some policy support with high effectiveness as platform. In the middle region, the role of green technology innovation policy is larger than in the west, probably which is because green technology innovation is developing in the middle region in China. In the western region, because of some infrastructure, funding and innovation resource constraints, green technology innovation is at the initial development stage.

\section{The Indirect Effect of Government Policy}

The results in all models suggest that enterprise innovation vitality can significantly promote green technology innovation, which is consistent with the results of Gong et al. (2020), Peng and Li (2018). But after adding policy variables, the coefficients of enterprise innovation vitality decrease. In combination with the empirical results of the extension model in Tables 5, 7, we can conclude that policy variables share and weaken the promoting effect of enterprise innovation vitality on green technology innovation. This result also indirectly verifies hypothesis 3 . Liu et al. (2020) also point that government subsidy policy is often used to encourage enterprises to carry out technology innovation activities, it will instead reduce the enterprise's R\&D spending. Enterprises can also use this funding for innovation in non-green technologies, so governments should not blindly provide subsidies and investments. Government can speed up establishing a market-oriented green technology innovation policy instead of giving direct subsidies for enterprises (Peng and Li, 2018). Only when market demand is improved can enterprises have a stronger self-drive for green technology innovation.

The results in most of models suggest government policies weaken the promoting effect of enterprise innovation vitality on green technology innovation. Hypothesis 3 is supported. There are different in interaction coefficients of policy variables and enterprise innovation vitality in eastern, middle and western regions. Policy variables have a significant and inhibiting effect on the promotion of enterprise innovation vitality on green 
technology innovation in middle regions. This is in line with the results from overall sample analysis. This is more likely because some western enterprises rely too heavily on government support. Western original innovation base is so backward, even with government support policies, enterprise cannot break the technology bottleneck and improve the effectiveness of green technology innovation. In the east, that inhibiting effect is not as significant. It may be due to the relatively stronger innovation vitality and more economic opportunities for eastern enterprises, but green technology innovation has not yet been supported by enterprise resources. Government policy have a positive and significant contribution to enterprise innovation vitality on green technology innovation in middle regions. The paper suggests that perhaps it is because the middle provinces has richer natural resources that are conducive to green technology innovation. Government-led is showing some performance on the promotion of enterprise innovation vitality on green technology innovation. Overall, government policies in the west and east regions still have a greater inhibiting effect on green technology innovation than they do in the middle regions.

\section{CONCLUSION, IMPLICATIONS AND FUTURE WORK}

\section{Conclusion}

To further explore the mechanism for the impact of comprehensive policy on green technology innovation, this study examined the role of government policies on green technology innovation using fixed effect (FE) model from three latitude including policy quantity, policy effectiveness and policy executive force. This study also extends the analysis of the interaction between government policy variables and enterprise innovation vitality on green technology innovation. The data used are provincial data in China from 2010 to 2019.

This paper draws four primary conclusions: First, the greater the number of green technology innovation policies, the higher the level of green technology innovation. It's the same result when it comes to policy effectiveness and policy executive force. The impact of present policies on green technology innovation is not as strong as the impact of cumulative policies. The positive impact of government policies on green technology innovation in the middle and western regions will be greater than in the eastern region. The positive impact of government policies on green utility patents will be greater than the effect on invention patents. Once the policy is promulgated, an adjustment period is necessary to maximize the effectiveness of the policy. Government policy, with its role of regulation, discipline, guidance and support, is actually very beneficial in improving green technology innovation in all Chinese provinces.

Second, the positive impact of policy executive force on green technology innovation is slightly smaller than policy quantity and effectiveness. Policy executive force is limited by the formulation of superior policy. At present, the improvement of green technology innovation is more dependent on the quantity advantage and effectiveness level of policies.

Third, at the current stage, green technology innovation policy restrains the promoting effect of enterprise innovation vitality on green technology innovation. But we think that this restriction will diminish as the green technology market improves and more enterprises abandon the pursuit of purely economic interests and become concerned about green sustainable development.

Fourth, from the empirical analysis results of eastern, middle and western regions, the policy impact on green technology innovation is indeed uneven. For three type of regions, the levels of direct impact and indirect impact of policy on green technology innovation are different, and the directions of indirect impact of policy are different.

\section{Policy Implications}

Technology innovation has long been a key driver of productivity growth, but some technology innovations can be harmful to environment protect while promoting economic development (Wang et al., 2021). Green technology innovation is one of the best ways for helping the region move towards sustainable growth. Although China has introduced policies to promote green technology innovation, it is still in a period of lead-in and development period (Song et al., 2020). As one of the key actors in policy implementation, local governments determine the policy effectiveness and are critical to achieving policy objectives.

Green technology innovation covers multiple industry segments, it is complex for policy making and is challenging for a single sector to cope with implementing policies. Local governments in China's provincial regions can benefit from the national focus on innovative development and green growth to improve their local green technology innovation policy systems. The direct and indirect impact of green technology innovation policy needs to be considered as well.

On the basis of ensuring the number of policies, the provincial governments should make more policies with high level of effectiveness level by integrating departments as strategic guidance, strengthen cross-sectoral coordination and cooperation and coordinate resources of relevant departments to enhance policy implementation and public sector efficiency. Local governments at all levels should ensure continuity of relevant policies and actively implement. It is necessary to coordinate policy objectives, the selection of policy instruments and the implementation of policies according to the development needs of regional green industries. It is useful to put into place more interdependent and complementary policy instruments.

Provincial governments may introduce policies associated with accountability mechanisms and incentives, strengthen the main role position of enterprises in green technology innovation, eliminate the negative impact of some policies on the promotion of green technology innovation by enterprises innovation vitality, improve regional green technology innovation capabilities.

Meanwhile, local governments should pay attention to develop support policies of green technology innovation based on original innovation resources. For the middle and western regions with imperfect economic and technological conditions, government can introduce more policies to help enterprises achieve technological breakthroughs and solve cost concerns. Local government can issue technology exchange policies to promote and apply green technologies across regions and enhance technological exchanges between universities, research institutes and even enterprises in different regions. In addition, local 
government also further formulate more attractive policies to help innovation subjects in middle and western regions recruit high-tech human capital resource. For the eastern region, it should to encourage to increase the effectiveness of innovation vitality in green technology innovation, promulgate international exchange policies, and supply the innovation subjects more opportunities to learn and introduce advanced technological knowledge. Each thoughtful government should promote the flow of green technology innovation resources across regions and find an appropriate green technology innovation pathway.

\section{Future Work}

The research has collected green patents and green technology innovation policy data, and included various provincial control variables for analysis, while the analysis of the heterogeneous impact of policies on different regional green technology innovation is not deep enough. This paper also doesn't consider the differences in the impact of government policies on green technology innovation of various industries. Therefore, future studies should focus on the impact of government policies on green technology innovation of various industries.

\section{DATA AVAILABILITY STATEMENT}

The original contributions presented in the study are included in the article/Supplementary Material, further inquiries can be directed to the corresponding author.

\section{REFERENCES}

Adler, K. B., Low, R. B., Leslie, K. O., Mitchell, J., and Evans, J. N. (1990). Contractile Cells in Normal and Fibrotic Lung. Sloan Manage. Rev. 32, 25-37. doi:10.1007/978-1-4612-0485-5 3

Bao, Q., Shao, M., and Yang, D. L. (2013). Environmental Regulation Provincial Legislation and Pollution Emission in China. Econ. Res. J. 48, 42-54. (In Chinese)

Bartlett, D., and Trifilova, A. (2010). Green Technology and Eco-innovation. Jnl Manu Tech. Mnagmnt 21, 910-929. doi:10.1108/17410381011086757

Bilgili, F., Kuşkaya, S., Ünlü, F., and Gençoğlu, P. (2019). Does Waste Energy Usage Mitigate the Co2 Emissions? a Time-Frequency Domain Analysis. Environ. Sci. Pollut. Res. 27, 5056-5073. doi:10.1007/s11356-019-07253-w

Bilgili, F., Nathaniel, S. P., Kuşkaya, S., and Kassouri, Y. (2021). Environmental Pollution and Energy Research and Development: an Environmental Kuznets Curve Model through Quantile Simulation Approach. Environ. Sci. Pollut. Res. 28, 53712-53727. doi:10.1007/s11356-021-14506-0

Chen, X., Li, M. L., and Zhang, Z. Z. (2019). Environmental Regulation,government Subsidies and green Technology Innovation--empirical research based on the mediation effect model. J. Ind. Technol. Econ. 38, 18-25. (In Chinese). doi:10.3969/j.issn.1004-910X.2019.09.003

Deng, F., and Chen, C. X. (2020). R\&D input intensity and China's green innovation efficiency-_based on the threshold of environmental regulation. J. Ind. Technol. Econ. 39, 30-36. (In Chinese). doi:10.3969/ j.issn.1004-910X.2020.02.004

Diercks, G., Larsen, H., and Steward, F. (2019). Transformative Innovation Policy: Addressing Variety in an Emerging Policy Paradigm. Res. Pol. 48, 880-894. doi:10.1016/j.respol.2018.10.028

Elahi, E., Abid, M., Zhang, L., ul Haq, S., and Sahito, J. G. M. (2018). Agricultural advisory and financial services; farm level access, outreach and impact in a

\section{AUTHOR CONTRIBUTIONS}

GW is responsible for the idea of the article, proofreading of the full text. QX is responsible for data collection, data processing, and draft writing. $\mathrm{XN}$ and $\mathrm{LT}$ is responsible for result analysis. $\mathrm{GW}, \mathrm{QX}$, and $\mathrm{XN}$ is responsible for the discussion. $\mathrm{XN}$ is responsible for submission of the manuscript.

\section{FUNDING}

This work was supported by the National Natural Science Foundation of China (grant numbers 71804105); the Philosophy and Social Science Planning Project of Shanghai City (grant numbers 2019BCK002); National Social Science Foundation of China (Key Program) (grant numbers 21AZD036); Youth Fund for Humanities and Social Sciences Research of the Ministry of Education (grant numbers 20YJC630108); Fundamental Research Funds for the Central Universities (grant numbers JKE022023004).

\section{ACKNOWLEDGMENTS}

We would especially like to thank Ziming Liu for his suggestions on this paper, thank Wenjing Guo and Tingyao Shi for his proofreading on this paper. We also would like to thank the editor section and reviewers.

mixed cropping district of Punjab, Pakistan. Land Use Policy 71, 249-260. doi:10.1016/j.landusepol.2017.12.006

Elahi, E., Khalid, Z., Tauni, M. Z., Zhang, H., and Lirong, X. (2021b). Extreme weather events risk to crop-production and the adaptation of innovative management strategies to mitigate the risk: A retrospective survey of rural Punjab, Pakistan. Technovation, 102255. doi:10.1016/j.technovation.2021.102255

Elahi, E., Khalid, Z., Weijun, C., and Zhang, H. (2020). The public policy of agricultural land allotment to agrarians and its impact on crop productivity in Punjab province of Pakistan. Land Use Policy 90, 104324. doi:10.1016/ j.landusepol.2019.104324

Elahi, E., Zhang, H., Lirong, X., Khalid, Z., and Xu, H. (2021a). Understanding cognitive and socio-psychological factors determining farmers' intentions to use improved grassland: Implications of land use policy for sustainable pasture production. Land Use Policy 102, 105250. doi:10.1016/j.landusepol.2020.105250

Etzkowitz, H. (2003). Innovation in innovation: the Triple Helix of universityindustry-government relations. Soc. Sci. Inf. 42, 293-337. doi:10.1177/ 05390184030423002

Evenson, R. E., and Griliches, Z. (1990). Griliches, Zvi. Technology, Education and Productivity: Essays in Applied Econometrics . Cambridge MA: Basil Blackwell, 1988, 378 pp., \$-49.95. Am. J. Agric. Econ. 72, 1098-1099. doi: $10.2307 / 1242649$

Fang, J.-W., and Chiu, Y.-h. (2017). Research on innovation efficiency and technology gap in China economic development. Asia Pac. J. Oper. Res. 34, 1750005. doi:10.1142/S0217595917500051

Feng, Z., and Chen, W. (2018). Environmental regulation, green innovation, and industrial green development: an empirical analysis based on the spatial durbin model. Sustainability 10, 223. doi:10.3390/su10010223

Fernando, Y., and Wah, W. X. (2017). The impact of eco-innovation drivers on environmental performance: empirical results from the green technology sector in Malaysia. Sustainable Prod. Consumption 12, 27-43. doi:10.1016/ j.spc.2017.05.002 
Gong, R., Wu, Y.-Q., Chen, F.-W., and Yan, T.-H. (2020). Labor costs, market environment and green technological innovation: evidence from high-pollution firms. Ijerph 17, 522. doi:10.3390/ijerph17020522

Guo, Q., Zhou, M., Liu, N., and Wang, Y. Y. (2019). Spatial effects of environmental regulation and green credits on green technology innovation under low-carbon economy background conditions. Ijerph 16, 3027. doi:10.3390/ijerph16173027

Guo, Y. (2018). The Research on the Effect of Innovation Policy on enterprise Innovation (Doctor Thesis). Xiamen, CHN: Xiamen University.

Guo, Y., Xia, X., Zhang, S., and Zhang, D. (2018). Environmental Regulation, Government R\&D Funding and Green Technology Innovation: Evidence from China Provincial Data. Sustainability 10, 940. doi:10.3390/su10040940

Hao, L.-N., Umar, M., Khan, Z., and Ali, W. (2021). Green growth and low carbon emission in G7 countries: how critical the network of environmental taxes, renewable energy and human capital is? Sci. Total Environ. 752, 141853. doi:10.1016/j.scitotenv.2020.141853

Haščič, I., and Migotto, M. (2015). Measuring environmental innovation using patent data. OECD Environ. Work. Pap. 89, 1-59. doi:10.1787/19970900

He, X. G. (2014). Research on optimal regulation structure of green technology innovation--based on the dual interactive effect of R\&D support and environmental regulation. Econ. Manag. 36, 144-153. (In Chinese). doi:10.19616/j.cnki.bmj.2014.11.016

Hong, J., She, Y., Wang, S., and Dora, M. (2019). Impact of psychological factors on energy-saving behavior: Moderating role of government subsidy policy. J. Clean. Prod. 232, 154-162. doi:10.1016/j.jclepro.2019.05.321

Hou, J., and Chen, H. (2018). Research on the green technological innovation performance and driving factors of high patent-intensive manufactures in China. Manag. Rev. 30, 59-69. (In Chinese). doi:10.14120/j.cnki.cn11-5057/ f.2018.04.006

Hu, S. M., Liu, S. L., Li, D., and Lin, Y. X. (2019). How does regional innovation capacity affect the green growth performance? Empirical Evidence from China. Sustainability 11, 1-21. doi:10.3390/su11185084

Ji, X., Umar, M., Ali, S., Ali, W., Tang, K., and Khan, Z. (2021b). Does fiscal decentralization and eco-innovation promote sustainable environment? A case study of selected fiscally decentralized countries. Sustainable Development 29, 79-88. doi:10.1002/sd.2132

Ji, X., Zhang, Y., Mirza, N., Umar, M., and Rizvi, S. K. A. (2021a). The impact of carbon neutrality on the investment performance: evidence from the equity mutual funds in BRICS. J. Environ. Manage. 297, 113228. doi:10.1016/ j.jenvman.2021.113228

Kuşkaya, S., and Bilgili, F. (2020). The wind energy-greenhouse gas nexus: The wavelet-partial wavelet coherence model approach. J. Clean. Prod. 245, 118872. doi:10.1016/j.jclepro.2019.118872

Leeuwen, G. v., and Mohnen, P. (2013). Revisiting the Porter hypothesis: An empirical analysis of green innovation for the Netherlands. SSRN J. 67, 295-319. doi: $10.2139 /$ ssrn. 2202920

Li, C., Liu, X., Bai, X., and Umar, M. (2020). Financial Development and Environmental Regulations: The Two Pillars of Green Transformation in China. Ijerph 17, 9242. doi:10.3390/ijerph17249242

Li, D., Wei, Y. D., Miao, C., and Chen, W. (2019). Innovation, innovation policies, and regional development in China. Geographical Rev. 110, 505-535. doi:10.1080/00167428.2019.1684194

Li, T., Liang, L., and Han, D. (2018). Research on the efficiency of green technology innovation in China's provincial high-end manufacturing industry based on the RAGA-PP-SFA model. Math. Probl. Eng. 2018, 1-13. doi:10.1155/2018/ 9463707

Li, Z.-Z., Li, R. Y. M., Malik, M. Y., Murshed, M., Khan, Z., and Umar, M. (2021). Determinants of carbon emission in China: how good is green investment? Sustainable Prod. Consumption 27, 392-401. doi:10.1016/j.spc.2020.11.008

Lin, J., Yu, Z., Wei, Y. D., and Wang, M. (2017). Internet Access, Spillover and Regional Development in China. Sustainability 9, 946. doi:10.3390/su9060946

Lin, Z., Wang, S., and Yang, L. (2020). Motivating innovation alliance's environmental performance through eco-innovation investment in a supply chain. J. Clean. Prod. 269, 122361. doi:10.1016/ j.jclepro.2020.122361

Liu, C., Gao, X., Ma, W., and Chen, X. (2020). Research on regional differences and influencing factors of green technology innovation efficiency of China's high-tech industry. J. Comput. Appl. Mathematics 369, 112597. doi:10.1016/j.cam.2019.112597
Ma, Y. Y., and Kong, M. H. (2017). An empirical analysis of Liaoning innovation policy and synergism effect on innovation performance. Theor. Horizon 530, 116-124+48. (In Chinese). doi:10.13221/j.cnki.lljj.2017.10.017

Martínez-Zarzoso, I., Bengochea-Morancho, A., and Morales-Lage, R. (2019). Does environmental policy stringency foster innovation and productivity in OECD countries? Energy Policy 134, 110982. doi:10.1016/j.enpol.2019.110982

OECD (1996). Economic Means in Environmental Management. Beijing, China: China Environmental Science Press.

Oliver, A. L., Montgomery, K., and Barda, S. (2020). The multi-level process of trust and learning in university-industry innovation collaborations. J. Technol. Transf 45, 758-779. doi:10.1007/s10961-019-09721-4

Pei, X., Jiang, A. X., and Ye, Y. (2019). Private investment, environmental regulation and green technological innovation-_analysis of spatial dubin model based on 11 provinces and cities in the Changjiang river economic belt. Sci. Technol. Prog. Pol. 36, 44-51.

Peng, B., Zheng, C., Wei, G., and Elahi, E. (2020). The cultivation mechanism of green technology innovation in manufacturing industry: from the perspective of ecological niche. J. Clean. Prod. 252, 119711. doi:10.1016/ j.jclepro.2019.119711

Peng, J. S., Zhong, W. G., and Sun, W. X. (2008). Policy measurement, policy coevolution and economic performance: An empirical study based on innovation policy. Manag. World 9, 25-36. (In Chinese). doi:10.19744/j.cnki.11-1235/ f.2008.09.003

Peng, Y. X., and Li, H. J. (2018). Research on influencing factor of green technology innovation in resource--based industries. Resour. Dev. Mark. 34, 1643-1650. doi:10.1080/02670836.2017.1421735

Qian, L., Wang, W. P., and Xiao, R. Q. (2018). Research on the regional disparities of China's industrial enterprises green innovation efficiency from the perspective of shared inputs. China Popul. Resour. Environ. 28, 27-39. (In Chinese). doi:10.12062/cpre.20171219

Ramanathan, R., Black, A., Nath, P., and Muyldermans, L. (2010). Impact of environmental regulations on innovation and performance in the UK industrial sector. Management Decis. 48, 1493-1513. doi:10.1108/00251741011090298

Ren, X. X. (2020). The combination of campaign governance and institutional construction: the strategy of economic institution transformation in China's reform and opening-up. J. Public Adm. 13, 3-21+195.

Rhodes, Ed., and Wield, D. (1994). Implementing New Technologies: Innovation and the Management of Technology. 2nd ed. Hoboken, NJ, USA: Wiley Blackwell.

Rogge, K. S., and Schleich, J. (2018). Do policy mix characteristics matter for lowcarbon innovation? A survey-based exploration of renewable power generation technologies in Germany. Res. Pol. 47, 1639-1654. doi:10.1016/ j.respol.2018.05.011

Shen, C., Li, S., Wang, X., and Liao, Z. (2020). The effect of environmental policy tools on regional green innovation: evidence from China. J. Clean. Prod. 254, 120122. doi:10.1016/j.jclepro.2020.120122

Shen, Y., Su, Z.-W., Malik, M. Y., Umar, M., Khan, Z., and Khan, M. (2021). Does green investment, financial development and natural resources rent limit carbon emissions? A provincial panel analysis of China. Sci. Total Environ. 755, 142538. doi:10.1016/j.scitotenv.2020.142538

Sheng, N., and Zhou, J. J. (2018). A study on China's green innovation efficiency evaluation and functional mechanism based on hybrid DEA and SEM model. J. Ind. Eng. Manag. 32, 46-53. (In Chinese). doi:10.13587/ j.cnki.jieem.2018.04.006

Sinn, H.-W. (2008). Public policies against global warming: A supply side approach. Int. Tax Public Finance 15, 360-394. doi:10.1007/s10797-008-9082-z

Song, M., Wang, S., Xie, Q., and Zhang, H. (2020). Could environmental regulation and R\&D tax incentives affect green product innovation? J. Clean. Prod. 258, 120849. doi:10.1016/j.jclepro.2020.120849

Umar, M., Ji, X., Mirza, N., and Naqvi, B. (2021). Carbon neutrality, bank lending, and credit risk: evidence from the Eurozone. J. Environ. Manage. 296, 113156. doi:10.1016/j.jenvman.2021.113156

Wang, B. B., and Zhao, C. (2019). China's green technological innovation-- patent statistics and influencing factors. J. Ind. Technol. Econ. 38, 53-66. (In Chinese). doi:10.3969/j.issn.1004-910X.2019.07.007

Wang, H., and Jin, Y. (2007). Industrial ownership and environmental performance: evidence from China. Environ. Resource Econ. 36, 255-273. doi:10.1007/s10640-006-9027-x 
Wang, H., Mamingi, N., Laplante, B., and Dasgupta, S. (2003). Incomplete executive force of pollution regulation: bargaining power of Chinese factories. Environ. Resour. Econ. 24, 245-262. doi:10.1023/A:1022936506398

Wang, K.-H., Umar, M., Akram, R., and Caglar, E. (2021). Is technological innovation making world "Greener"? An evidence from changing growth story of China. Technol. Forecast. Soc. Change 165, 120516. doi:10.1016/ j.techfore.2020.120516

Wang, Q., Qu, J., Wang, B., Wang, P., and Yang, T. (2019). Green technology innovation development in China in 1990-2015. Sci. Total Environ. 696, 134008. doi:10.1016/j.scitotenv.2019.134008

Wang, X., and Chu, X. (2019). External financing and enterprises' green technology innovation: a study based on the threshold model of firm size. Syst. Eng. Theor. Pract. 39, 2027-2037. (In Chinese). doi:10.12011/1000-6788-2018-1350-11

Wang, X., Liu, Y., and Ju, Y. (2018). Sustainable Public Procurement Policies on Promoting Scientific and Technological Innovation in China: Comparisons with the U.S., the UK, Japan, Germany, France, and South Korea. Sustainability 10, 2134. doi:10.3390/su10072134

Wang, X., and Zou, H. (2018). Study on the effect of wind power industry policy types on the innovation performance of different ownership enterprises: evidence from china. Energy Policy 122, 241-252. doi:10.1016/j.enpol.2018.07.050

Weng, Y. J., Ma, W. C., Ye, P. Y., and Zhang, G. Y. (2018). The evolving characteristics, problems and countermeasures of LED industry policy in China: three dimensional analysis based on policy objectives, policy tools and policy strength. Sci. Technol. Manag. Res. 38, 69-75. (In Chinese). doi:10.3969/j.issn.1000-7695.2018.03.012

Wintoki, M. B., Linck, J. S., and Netter, J. M. (2012). Endogeneity and the dynamics of internal corporate governance. J. Financial Econ. 105, 581-606. doi:10.1016/ j.jfineco.2012.03.005

Wu, G. Z., and You, D. M. (2019). The influence mechanism of environmental regulation on technology innovation and green total factor productivity: Based on the moderating effect of fiscal decentralization. J. Ind. Eng. Manag. 33, 37-50. (In Chinese). doi:10.13587/j.cnki.jieem.2019.01.005

Xiao, L. M., Gao, J. F., and Han, B. (2018). Spatial spillover effects of provincial green innovation efficiency in China--homogeneity and heterogeneity test. J. Ind. Technol. Econ. 37, 30-38. (In Chinese). doi:10.3969/j.issn.1004910X.2018.04.004

Xu, J. Z., Wang, M. M., and Guan, J. (2019). Research on mechanism of carbon emission from energy consumption and green innovation efficiency in dynamic endogenous perspective based on Chinese equipment manufacturing industries. Manag. Rev. 31, 81-93. (In Chinese). doi:10.14120/j.cnki.cn115057/f.2019.09.007

Yan, Y., and Wu, Z. (2020). Regional innovation distribution and its dynamic evolution: Policy impact and spillover effect-Based on the perspective of innovation motivation. PLOS ONE 15, e0235828-29. doi:10.1371/ journal.pone. 0235828

Yang, F. T. (2016). Practical experience of green technology innovation system in foreign countries. Part. Gov. Vis. 3, 42.

Yi, M., Fang, X., Wen, L., Guang, F., and Zhang, Y. (2019). The heterogeneous effects of different environmental policy instruments on green technology innovation. Ijerph 16, 4660. doi:10.3390/ijerph16234660
Yu, B., Li, C., Mirza, N., and Umar, M. (2022). Forecasting credit ratings of decarbonized firms: comparative assessment of machine learning models. Technol. Forecast. Soc. Change 174, 121255. doi:10.1016/j.techfore.2021.121255

Yuan, B., and Zhang, Y. (2020). Flexible environmental policy, technological innovation and sustainable development of China's industry: The moderating effect of environment regulatory enforcement. J. Clean. Prod. 243, 118543. doi:10.1016/j.jclepro.2019.118543

Zeng, J. H., Liu, S. Q., and Li, J. W. (2020). Research on the relationship between multi-driven green innovation and corporate performance. J. Ind. Technol. Econ. 39, 13-22.

Zhang, G. X., Feng, Y. C., and Wang, A. L. (2021). The heterogeneous effects of different types of environmental regulation on technological innovation of industrial enterprises. Manag. Rev. 33, 92-102. (In Chinese). doi:10.14120/ j.cnki.cn11-5057/f.2021.01.007

Zhang, J., Geng, H., Xu, G. W., and Chen, J. (2019). Research on the influence of environmental regulation on green technology innovation. China Popul. Resour. Environ. 29, 168-176. (In Chinese). doi:10.12062/cpre.20180917

Zhang, K. (2019). Interaction and spatial spillover between economic agglomeration and regional innovation. J. Financial Res. 5, 96-114.

Zhang, W., Fei, X. Y., and Fang, H. (2016). Design and construction of evaluation index system of regional innovation policy based on a multi-perspective. Sci. Technol. Prog. Pol. 33, 142-147. (In Chinese). doi:10.6049/ kjjbydc.2015060401

Zhao, Y., Peng, B., Elahi, E., and Wan, A. (2021). Does the extended producer responsibility system promote the green technological innovation of enterprises? An empirical study based on the difference-in-differences model. J. Clean. Prod. 319, 128631. doi:10.1016/j.jclepro.2021.128631

Zhou, X., Yu, Y., Yang, F., and Shi, Q. (2021). Spatial-temporal heterogeneity of green innovation in China. J. Clean. Prod. 282, 124464. doi:10.1016/ j.jclepro.2020.124464

Zygiaris, S. (2013). Smart city reference model: assisting planners to conceptualize the building of smart city innovation ecosystems. J. Knowl Econ. 4, 217-231. doi:10.1007/s13132-012-0089-4

Conflict of Interest: The authors declare that the research was conducted in the absence of any commercial or financial relationships that could be construed as a potential conflict of interest.

Publisher's Note: All claims expressed in this article are solely those of the authors and do not necessarily represent those of their affiliated organizations, or those of the publisher, the editors and the reviewers. Any product that may be evaluated in this article, or claim that may be made by its manufacturer, is not guaranteed or endorsed by the publisher.

Copyright $\odot 2022 \mathrm{Wu}, \mathrm{Xu}$, Niu and Tao. This is an open-access article distributed under the terms of the Creative Commons Attribution License (CC BY). The use, distribution or reproduction in other forums is permitted, provided the original author(s) and the copyright owner(s) are credited and that the original publication in this journal is cited, in accordance with accepted academic practice. No use, distribution or reproduction is permitted which does not comply with these terms. 